ECCOMAS

Proceedia
COMPDYN 2021

$8^{\text {th }}$ ECCOMAS Thematic Conference on Computational Methods in Structural Dynamics and Earthquake Engineering M. Papadrakakis, M. Fragiadakis (eds.) Streamed from Athens, Greece, 28 - 30 June 2021

\title{
FRAGILITY CURVES FOR ITALIAN RESIDENTIAL MASONRY BUILDINGS WITH RETROFIT INTERVENTIONS
}

\author{
Veronica Follador ${ }^{1,3}$, Marco Donà ${ }^{2,3}$, Pietro Carpanese ${ }^{3}$, and Francesca da Porto ${ }^{3}$ \\ ${ }^{1}$ Depart. of ICATAM - University of Brescia \\ Via Branze, 43, 25123, Brescia (IT) \\ v.follador@unibs.it \\ ${ }^{2}$ Earthquake Engineering Research \& Test Center - Guangzhou University \\ Guang Yuan Zhong Rd. 248, 510405 Guangzhou, China \\ dona_marco@gzhu.edu.cn \\ ${ }^{3}$ Depart. of Geosciences - University of Padova \\ Via G. Gradenigo, 6, 35131 Padova, Italy \\ veronica.follador@unipd.it,marco.dona.1@unipd.it, pietro.carpanese@phd.unipd.it, \\ francesca.daporto@unipd.it
}

\begin{abstract}
The earthquakes of the last decades have shown that the Italian residential masonry built heritage has high seismic vulnerability, in particular when considering structures built before 1919. For this reason, it is necessary to develop effective large-scale risk mitigation strategies in order to reduce the huge losses that could occur in the aftermath of an earthquake. In this paper some retrofit interventions applicable mainly to old buildings are presented, explaining their advantages and potential. These interventions are then implemented, through Vulnus 4.0 software, on a database of 205 buildings built before 1919, previously analyzed in their as-built state.

Fragility curves are then developed for each building, and are processed in order to create a vulnerability model for different construction periods that takes into account the possible retrofit intervention strategies. Therefore, this procedure allows a comparison between pre and post retrofit intervention fragility, and the results in terms of curves can be used for large scale damage and risk simulations.
\end{abstract}

Keywords: Residential Masonry Buildings, Territorial-Scale Seismic Vulnerability, Fragility Model, Retrofit intervention. 


\section{INTRODUCTION}

Over the last decades, Italy has been affected by very impactive seismic events, which caused thousands of casualties and around 180 billion euros of economic losses, in terms of recovery and reconstruction costs [1]. It is clear that those high economic and human costs are no longer sustainable, and large-scale mitigation policies need to be pursued.

In this context, Italian institutions (in particular the Department of Civil Protection - DPC) are working in synergy with the scientific community to find effective seismic risk mitigation strategies [1-3]. In particular, the work presented in this paper is part of a project carried out by ReLUIS (Network of University Laboratories for Earthquake Engineering) and EUCENTRE (European Centre for Training and Research in Earthquake Engineering), and coordinated by DPC. The aim of the project is to develop large scale vulnerability models for consolidated buildings, and then to perform cost-benefit analyses that can give an estimate of the payback time of seismic retrofit interventions. The final purpose is to elaborate mitigated risk maps that simulate different preventive strategies, thus making it possible to identify prioritization and convenience ranking for the different interventions.

In order to do so, one must assess the variation of seismic vulnerability between the as-built configuration and the case where particular seismic retrofit interventions were performed. The estimation of seismic vulnerability, i.e. the propensity of structures to suffer damage after a seismic event of a given intensity, is usually defined by fragility curves. A fragility curve is a probabilistic distribution that expresses the probability of occurrence of a certain damage state in relation to seismic intensity. Usually, lognormal cumulative fragility curves are used [4].

In literature there are several methods to define fragility curves: a) empirical methods, in which fragility curves are calibrated from damage data survey in areas affected by seismic events [5-8]; b) analytical (mechanical) methods, based on structural models and analyses that simulate the seismic behavior of buildings [9-13]; and c) hybrid methods, which have characteristics from both a) and b) methods [14].

In this study, a mechanical simplified procedure was used to obtain fragility curves for Italian residential masonry buildings with eight different types of intervention. This study focuses on residential historical buildings: these are usually stone (mainly random) and solid brick masonry buildings, with timber floors and roofs and in most cases without any retaining elements, such as tie-rods or beams. In particular, buildings dating from before 1919 were analyzed, as they represent the $29.4 \%$ of the Italian masonry heritage and the $18.1 \%$ of the entire Italian residential building stock [15], but made for the most of damage observed in recent events.

The paper firstly presents the most common seismic retrofit interventions in Italy for the analyzed building type, and defines the main modifications that these interventions produce in structural and mechanical parameters. Then, the selected interventions were simulated in a database composed of 205 Pre-1919 masonry buildings. The program used for the analysis and the elaboration of the fragility curves is the Vulnus vb 4.0 software $[16,17]$.

Then, the curves obtained by Vulnus are post-processed according to the Donà et al. [18] methodology, in order to obtain a single fragility model.

\section{INTERVENTIONS FOR SEISMIC RETROFIT OVERVIEW}

Interventions for seismic improvement can be grouped in the following categories [19, 20] according to their aim: a) interventions targeting strength and compactness of walls; b) interventions that improve connections, and c) interventions aimed at strengthening and stiffening horizontal diaphragms. 


\subsection{Masonry strengthening and compacting}

In case of historical ordinary buildings, the materials that compose the load-bearing stone masonry structure are often not very performing in terms of mechanical characteristics. Several techniques can be applied to improve masonry performance, provided a careful evaluation of the most suitable intervention with respect to the typology and the quality of the masonry is previously carried out [19-21].

When the stone masonry is inconsistent and characterized by the presence of voids (two or three leaves masonry), the most used and effective interventions are grout or mortar injections [22-24]. This type of intervention consists in the grouting of the wall's core through a regular pattern of drilled holes, previously cleaned by water or compressed air. Injections are performed from the bottom to the top of the walls with controlled pressure.

In case of damaged or inconsistent masonry, it is also possible to realize reinforced concrete jackets [25] made of cement or lime-based mortars and a steel mesh or fabrics reinforcement. To the ends of a successful intervention, the reinforcements on both sides need to be well anchored to the wall by the means of transversal connections (Figure 1a).

With stone ashlar or brick masonry, but either with poorly performing resistant elements or poor quality mortars, the most suitable interventions are bed-joint repointing (also reinforced with metal bars) or the application of FRCM-TRM (Fibre/Fabric Reinforced Cementitious Matrix/Mortar - Textile Reinforced Mortars) plasters [26, 27]. The latter consists of reinforced plasters made with glass, carbon, aramid or polypropylene fiber meshes, coated in inorganic matrices based on lime or cement mortar. These reinforcements can be widespread to the entire surface of the walls or applied locally (Figure 1b) [28, 29].

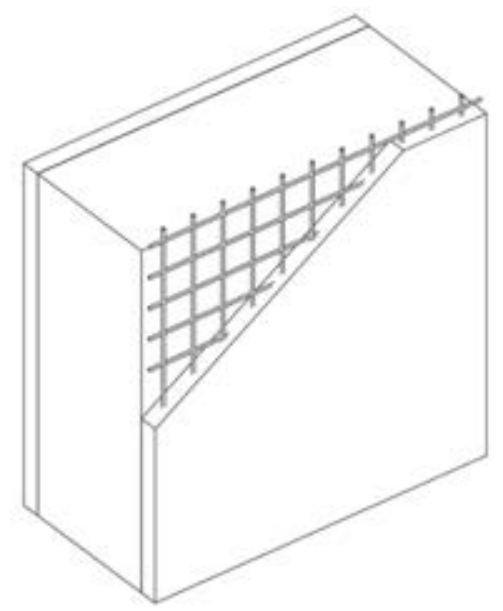

a)

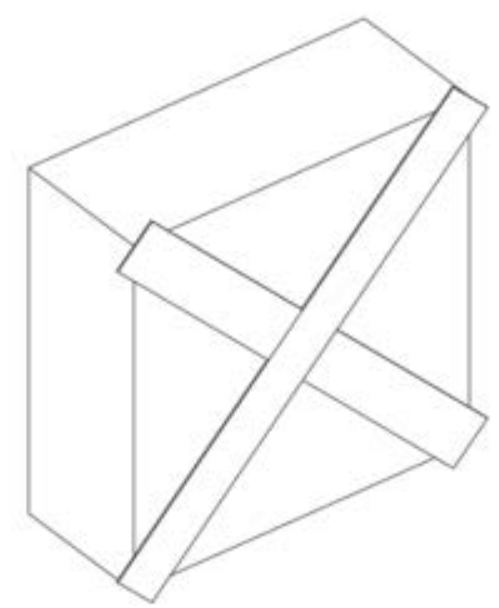

b)

Figure 1: Reinforced concrete jackets (a) and example of application of FRCM-TRM (b).

The condition of multiple leaves that are not adequately connected to each other can occur in both brick and stone masonry. In order to guarantee the overall functioning of the wall, it is possible to insert artificial transverse elements in its thickness (made of reinforced concrete or metal profiles), or metal tie-rods (made of smooth or threaded bars) with an anti-expulsion function $[22,22]$. This type of intervention is feasible only if the masonry is consistent enough to ensure the solidarization between the faces.

\subsection{Improvement of connections and box-like behavior}

The seismic behavior of existing masonry buildings also depends on the connections between structural elements (wall-to-wall and wall-to-floor). These connections are necessary to 
enable the global behavior of the building and to prevent the activation of out-of-plane mechanisms, however they are generally inadequate in more ancient buildings.

The connections among the walls can be obtained through local interventions, although the application of connecting elements between parallel opposite walls (such as steel tie-rods and cables or external confining rings) has proved to be one of the most effective [19,25]; moreover, tie-rods are a traditional technique which is also highly compatible. Usually, steel threaded bars are placed at floor levels, in the two main directions of the building, along the load-bearing walls, although in more recent times they may also have been combined with diagonally crossed systems. Tie-rods must be positioned at floor level in conjunction with the nodes (along external and inside walls, Figure 2a).

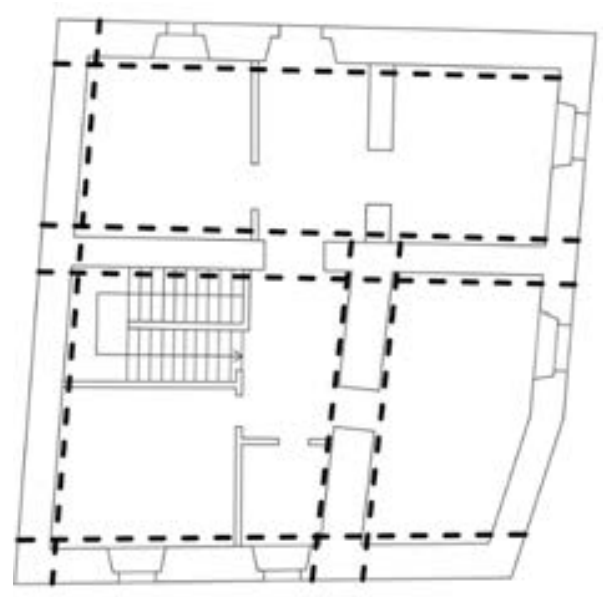

a)

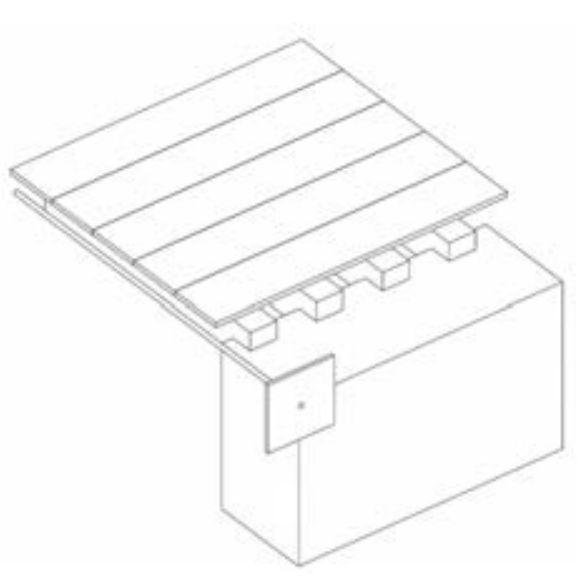

b)

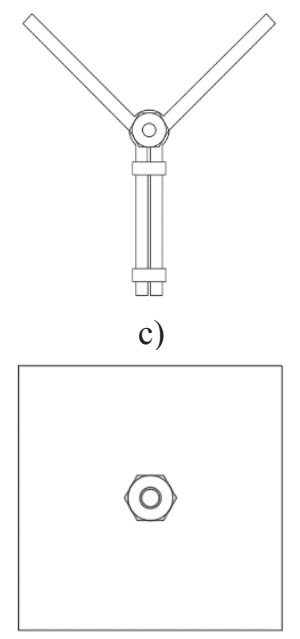

d)

Figure 2: Ties positioning (a, b) and examples of external anchors $(c, d)$.

In general, the tie-rods placed on the upper levels of the building have a crucial role for the local equilibrium of the walls. For an effective intervention, the contrasting masonry must be sufficiently consistent and resistant to sustain the local force applied by a tie's anchor; for this reason, localized interventions are recommended, such as hydraulic mortar injections, reinforcement or replacement of individual degraded elements, assuming that the general state of the masonry is sufficiently good.

Another possible intervention is the insertion of tie-beams just at the top or at all levels of a building. According to past Italian seismic codes $[30,31]$ they must have been made of reinforced concrete, but this was recently proved to be more detrimental than beneficial to seismic behavior as a consequence of high weight and poor compatibility with random masonry [19, $20,32]$. Therefore, a new generation of tie beams was proposed, adopting reinforced masonry or steel structural shapes [33].

\subsection{Strengthening and stiffening of horizontal diaphragms}

Horizontal diaphragms in seismic conditions should redistribute horizontal loads from loadbearing walls orthogonal to the earthquake direction to those parallel to it, in order to oppose the highest strength.

Timber floors are based on the assembly of overlapping elements, which are able to withstand and distribute vertical stresses, but not horizontal ones. This is due to the lack of adequate connections between the elements of the horizontal structure (inadequate in-plane stiffness) and between the horizontal structure and the vertical one (inadequate wall to floor connection). 
Considering the fundamental partitioning action of floors, interventions aim at not only decreasing plan deformability, but also strengthening the connections between floors and walls have to be performed. However, an excessive strengthening, like that obtained by floor replacement with reinforced concrete slabs, would be ineffective, or even pejorative from a seismic retrofit point of view [20,34].

For what concerns historical buildings, several techniques have been developed respecting traditional construction practice and avoiding at the same time the negative increase of weight at the floor level [26].

Some examples of interventions that improve the diaphragm action are wooden planking and application of diagonal metallic belts or composite material strips. These interventions can be executed on the intrados or on the extrados of the floor. With regard to residential buildings without valuable floors, interventions on the extrados are preferable.

In order to increase the in-plane stiffness, the addition of single or double wooden planks over the existing one can be considered (in orthogonal direction or at $45^{\circ}$, using tongue-andgroove joints with nails or screws as connectors) [35, 36] (Figure 3).

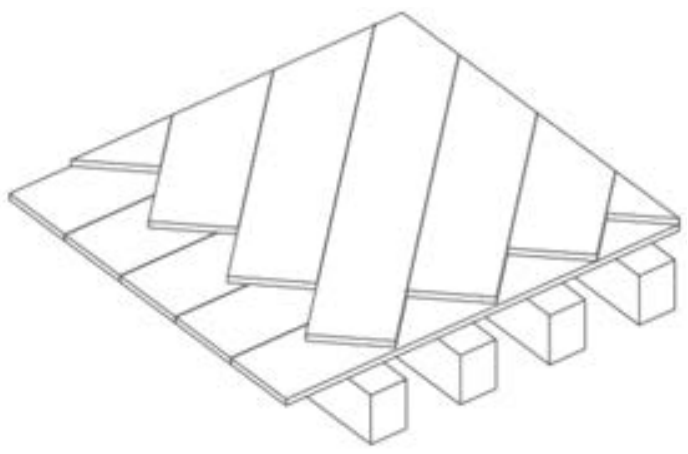

a)

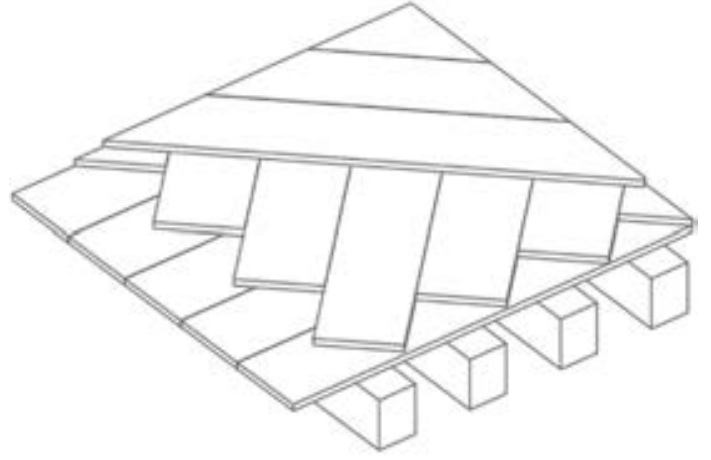

b)

Figure 3: Reinforced timber floor with single planking inclined at $45^{\circ}$ (a); reinforced timber floor with double planking crossed at $+45^{\circ}$ and $-45^{\circ}$ (b).

Interventions that do not modify floor stiffness but assure an adequate connection with walls are perimeter steel plates anchored with dowels to the walls [37] and distributed anchors at the ends of floor joists. These have to be injected with mortars or resins on the wall, or anchored externally; on the inner side, they have to be nailed to joists or upper boards, thus binding the floor to the wall (Figure 4) [38, 39].

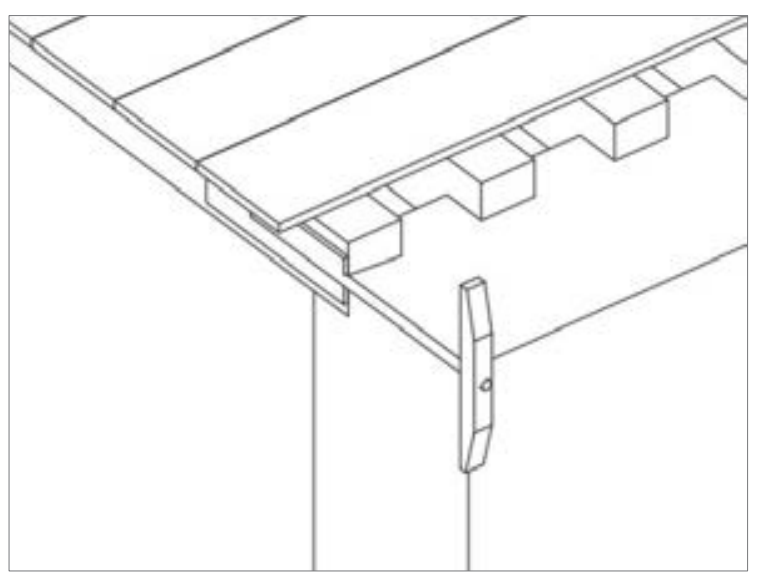

Figure 4: Example of connection floor-to-wall. 


\section{ANALYSIS TOOL AND IMPLEMENTATION OF INTERVENTIONS}

Once the best performing retrofit interventions were analyzed, it was possible to select the most suitable method and tools to start the implementation phase.

\subsection{Analysis method}

The software used for the analysis is Vulnus vb 4.0 [16, 17], originally developed by A. Bernardini, R. Gori and C. Modena (University of Padova). Vulnus can analyze load-bearing masonry structures through limited information (geometry, material properties, construction details, qualitative information) by means of limit analysis.

The Vulnus methodology is based on the calculation of the critical horizontal accelerations that cause the activation of the main out-of-plane collapse mechanisms for each wall, and inplane shear failure of the two main parallel wall systems. These critical accelerations are then normalized to gravity acceleration $g$ and returned in terms of indices $I 1$ and $I 2$ for the in-plane and out-of-plane response, respectively.

More specifically, the index II represents the shear resistance calculated on the weakest direction of the building, eventually corrected in case of irregularities that may cause non-uniform distributions of normal and tangential stresses. On the other hand, the index $I 2$ depends on the possible out-of-plane kinematic mechanisms and it corresponds to the minimum value of the sum of two sub-indices, $I 2^{\prime}$ and $I 2^{\prime \prime}$. In particular, $I 2^{\prime}$ evaluates a building's resistance to mechanisms which involve a vertical strip of its walls (overall overturning of the wall, overturning and flexural failure of the top storey). I2" instead evaluates the resistance to mechanisms developing across the breadth of a walls (horizontal masonry strips): a) bending and arching mechanism failure, b) overturning and flexural collapse of the arch shoulders, and c) detachment of the transverse walls, always at the last storey.

In addition, a third index $I 3$ represents qualitative features of the building (not included in the other two indices). I3 is calculated as the weighted normalized sum (between 0 and 1) of the scores derived by the "Second Level" form of GNDT [40]. Specifically, the form consists of 11 parameters, to which a quality class form A to D (where A is the best condition) is assigned; each qualitative class is then associated to a numerical score.

Once the three indices $I 1, I 2$ and $I 3$ have been calculated, Vulnus performs a vulnerability analysis using the fuzzy sets theory. The fuzzy approach allows to consider uncertainties associated to those parameters which are not directly measured and to the variability of the mechanical characteristics of the materials.

Using this approach, Vulnus calculates three fragility curves, which represent the mean (White curve) and the extreme probabilities (Lower-Bounds and Upper-Bounds curves) of reaching or exceeding the triggering acceleration of in-plane or out-of-plane mechanisms. For this reason, the damage state (DS) associated to the resulting fragility curves is a DS2-3, with reference to the scale proposed by the European Macroseismic Scale (EMS-98) [41].

\subsection{Implementation of retrofit interventions}

On the basis of the considerations presented in section 2 and of direct field observations [32, 42], some interventions were considered as the most effective for Pre-1919 buildings. These interventions are presented in Table 1.

Vulnus allows to carry out simplified vulnerability analyses of masonry buildings. This implies that interventions must also be implemented in a simplified way. In fact, some intervention could be directly implemented by the options already present in the software, whereas others had to be implemented indirectly, reproducing the effect of the intervention on the building's overall behavior. 
The implementation methodology of the selected interventions is presented below. Some interventions were also implemented in combination (as shown in Table 1).

individual interventions

\begin{tabular}{ll}
\hline MSN1 & $1^{\text {st }}$ stage \\
MSN2 & $2^{\text {nd }}$ stage of masonry strengthening (stone: injection - brick: reinforced plaster) \\
TR & addition of tie-rods \\
FLR & stiffening of floors (light interventions) \\
\hline
\end{tabular}

combined interventions

\begin{tabular}{ll}
\hline MSN1+TR & first stage of masonry strengthening + addition of tie-rods \\
MSN1+FLR & first stage of masonry strengthening + stiffening of floors \\
MSN2+TR & second stage of masonry strengthening + addition of tie-rods \\
MSN2+FLR & second stage of masonry strengthening + stiffening of floors \\
\hline
\end{tabular}

Table 1: Implemented retrofit interventions.

Two stages of retrofit interventions of strengthening of masonry are proposed. The first stage (MSN1) considers the application of light or single interventions, whereas the second one (MSN2) implies the concurrent application of more types of intervention or the implementation of a single intervention with all possible expedients to ensure the best results. The masonry interventions proposed in this study, according to the type of masonry, are: on random multileaf stone mainly injections are suggested, whereas the application of FRCM-TRM reinforced plaster is preferred in the case of stone ashlars or brick masonry. To simulate these interventions through Vulnus, the corrective coefficients shown in Table 2 were applied. The coefficients refer to table C8.5.II available in [43], and represent a medium increase of the mechanical characteristics of the materials composing the building owing to different type of intervention. It can be observed that the first step brings a similar improvement among different masonry types. Instead, the implementation of more invasive and heavy interventions on stone masonry, characterized by values of the mechanical parameters lower than the ones associated to brick masonry, gives greater improvements, although not exceeding the values of the mechanical characteristics of brick masonry. Lastly, the interventions considered require the addition of material, which is estimated to determine an average increase of masonry specific weight by $5 \%$.

\begin{tabular}{lcc} 
& MSN1 & MSN2 \\
\hline Stone masonry & 1.7 & 2.4 \\
Solid brick masonry & 1.5 & 1.8 \\
Tuff masonry & 1.6 & 1.9 \\
\hline
\end{tabular}

Table 2: Multiplicative coefficients used.

The insertion of tie-rods (TR) was directly implemented in Vulnus. In fact, the software provides the possibility to enter the number of ties present in both main directions of the building. TR intervention was implemented by placing, for each main direction of the building, an adequate number of rods (two rods, one per side, placed parallel to the internal partitions, and one rod to the perimeter walls). 
As regards to floor interventions (FLR), the most effective solutions for historical buildings are the insertion of bracing systems or the installation of double wooden planks, in order to increase the stiffness without overloading. Since in Vulnus floor types determine just the dead loads on walls, diffuse chains have been placed to simulate the improved box-like behavior when floors are stiffened. In addition, to further increase the diaphragms' reaction of the model, the floor-to-wall friction coefficient was increased to account for the improved connection achieved by the intervention.

In order to update the class of the Second Level GNDT form parameters, used by Vulnus to elaborate the final curves, the modifications that each intervention brings to the as-built configuration were studied. Of the 11 parameters of the form, those linked to the interventions analyzed are: quality of the resistant system, floor type, roof type and state of maintenance. The value assigned to other parameters in as-built conditions was maintained in strengthened ones. In Table 3 the adopted changes, made with reference to the manual of the form [40], are reported.

\begin{tabular}{|c|c|c|c|c|c|}
\hline GNDT parameter & $\begin{array}{l}\text { MSN1 } \\
\text { MSN2 } \\
\end{array}$ & TR & FLR & $\begin{array}{l}\text { MSN1+TR } \\
\text { MSN2+TR }\end{array}$ & $\begin{array}{l}\text { MSN1+FLR } \\
\text { MSN2+FLR }\end{array}$ \\
\hline Resistant system & A & & & A & $\mathbf{A}$ \\
\hline Floors & & & A & & A \\
\hline Roof & & +1 class & +1 class & +1 class & +1 class \\
\hline State of maintenance & $\mathbf{A}$ & & & A & A \\
\hline
\end{tabular}

Table 3: Modified classes for the GNDT parameters considered.

\section{FRAGILITY MODEL WITH RETROFIT INTERVENTIONS}

The present study is in continuity with past analyses $[44,45]$ in which a database of more than 500 buildings was analyzed using Vulnus 4.0 and fragility sets were obtained for ten macro-types (five age and two height classes) of as-built residential masonry buildings. Specifically, the eight interventions identified in the previous chapters have been implemented on those 205 buildings which belonged to the Pre-1919 macro-typology of the original database. Then, the elaboration of the specific fragility sets for each intervention was carried out following the procedure proposed by Donà et al. [18].

\subsection{Methodological approach}

As already mentioned, the Vulnus software produces three fragility curves associated with an average probability (White) and two extreme probabilities (Upper- and Lower-Bounds), corresponding to a damage state DS2-3.

In order to define a single fragility model for the two macro-typologies considered in this study (Pre-1919 Low-Rise buildings, i.e. 1 and 2 floors, and Pre-1919 Mid-Rise buildings, i.e. 3, 4 and 5 floors), in the first place the White, Upper- and Lower-Bounds curves were processed separately. The curves of each building were averaged firstly by municipality, in order to maintain a geographical representativeness, and then by number of floors and age of construction, considering for each sub-typology the actual real distribution obtained from 2001 ISTAT census data [15].

Subsequently, the fragility model of Lagomarsino and Cattari [10] was calibrated on the mechanical fragility model obtained for DS2-3, in order to represent seismic fragility over the five damage states (from DS1 to DS5). In this way, a new mechanically based heuristic fragility model was derived. 
Lastly, the different sets obtained for White, Upper- and Lower-Bounds were combined, with the aim of developing a single fragility set (LUW). This operation allows to maintain the average fragility defined by the White curves (assumed as the most likely fragility), but at the same time to increase the dispersion parameter, thus resulting more suitable to represent the vulnerability of the built stock on a large scale.

In Figure 5, the main steps of this procedure [18] are presented.



Figure 5: Procedure used to define the mechanical-heuristic fragility model from the mechanical one obtained through Vulnus [18].

\subsection{Fragility sets and results}

The procedure presented in $\S 4.1$ was recursively carried out for each intervention considered. In this way, the fragility sets related to the Pre-1919 buildings for the two height classes LowRise (1 and 2 storeys) and Mid-Rise (3, 4 and 5 storeys) were obtained, and it was possible to compare the fragility curves of the as-built configuration with the curves obtained after the simulation of the interventions.

It should be noticed that, despite the validity of the method [18], the models presented below (Figure 6) do not allow to evaluate the effects that the interventions may produce limited to some DSs (e.g. reduction of severe damage but not of slighter one), but provide just an overall indication of their effectiveness.

As expected, the graphs in Figure 6 show that the greatest variation in vulnerability occurs with the application of combined interventions. Considering individual interventions, the insertion of tie-rods (TR) produces underperforming results, while the intervention on floors (FLR) gives slightly better outcomes. The greatest effectiveness derives from two-steps interventions applied to increase masonry strength and compactness (MSN1, MSN2). When the floors or ties interventions are combined with masonry strengthening (MSN1+FLR, MSN1+TR, MSN2+FLR, MSN2+TR), the floors interventions appears to be more effective than the tierods ones.

Furthermore, the different effectiveness of interventions in Low-Rise and Mid-Rise buildings can be examined. The interventions on the floors and those related to the insertion of tierods are more effective if applied to Low-Rise buildings, whereas for Mid-Rise buildings the vulnerability reduction is smaller. This leads to the conclusion that the height of the building plays a fundamental role in the variation of vulnerability. 
FLR

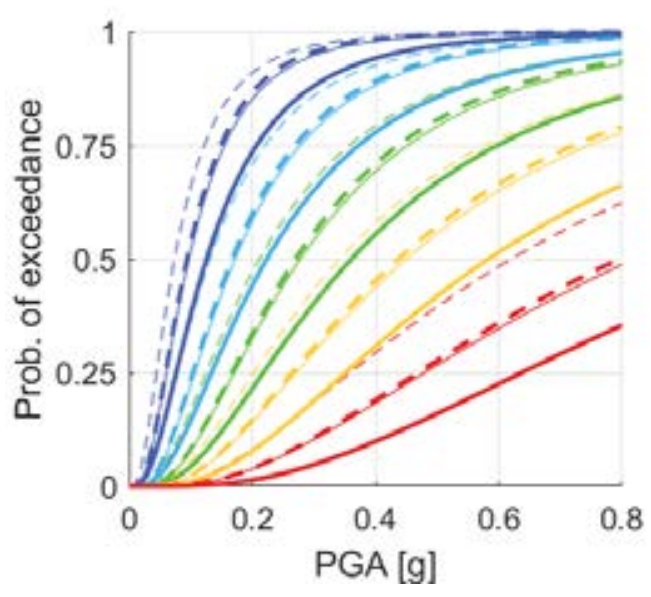

MSN1

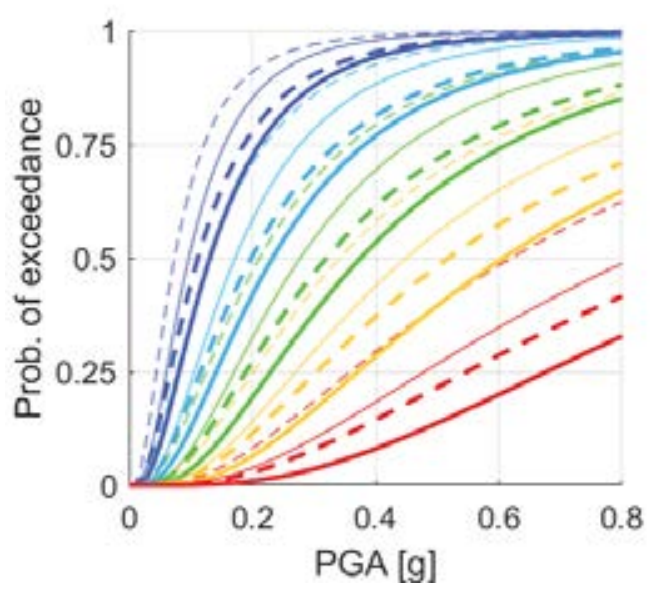

MSN1+FLR

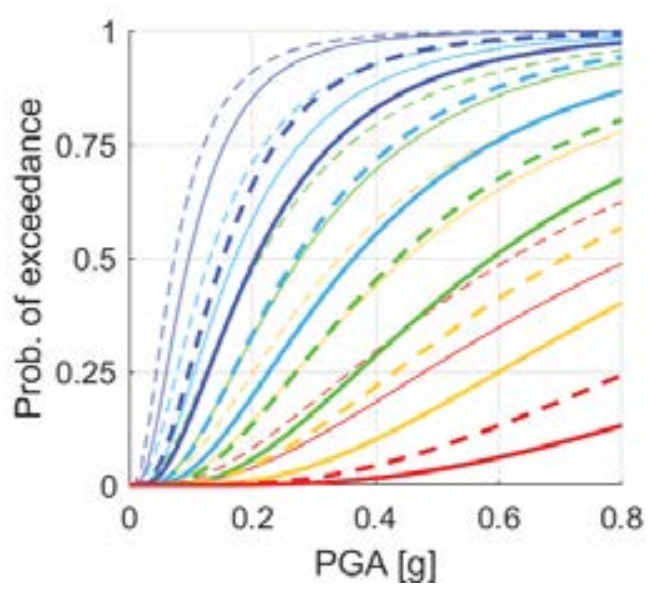

TR

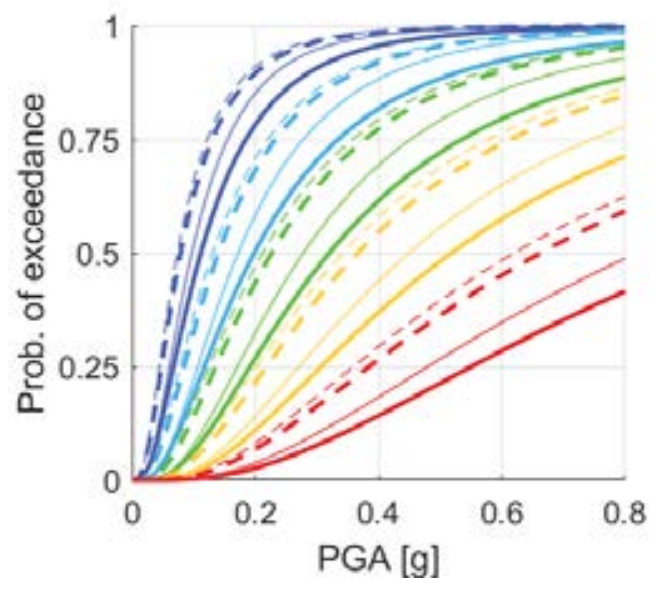

-DS1

-DS2

-DS3

DS4

-DS5

- Low-Rise

-..- Mid-Rise

- As-built

- Retrofit

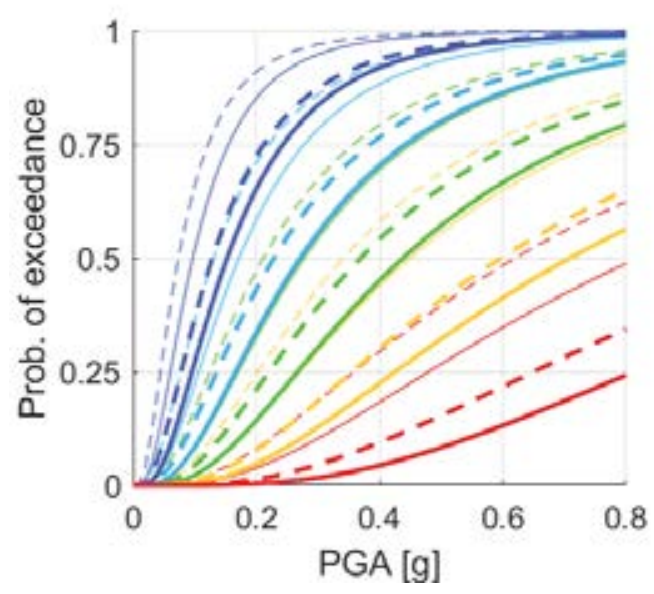

\section{MSN1+TR}

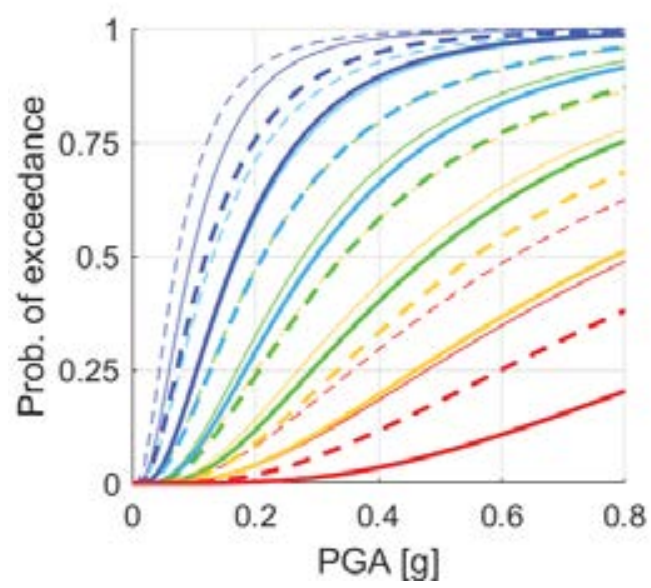


MSN2+FLR

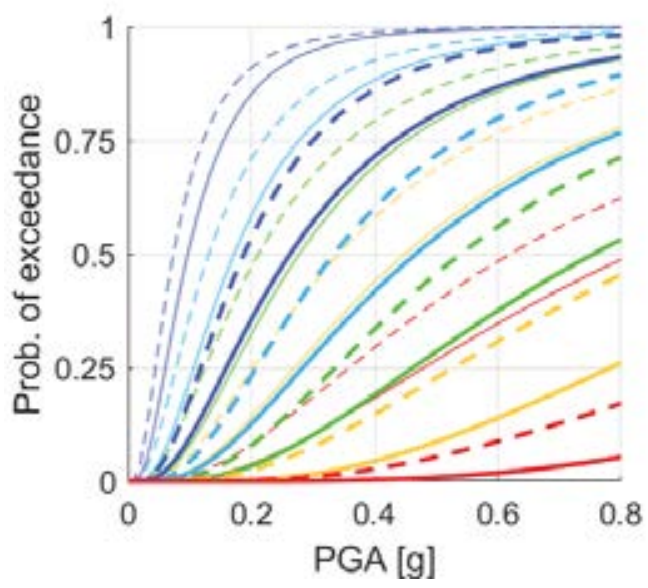

MSN2+TR

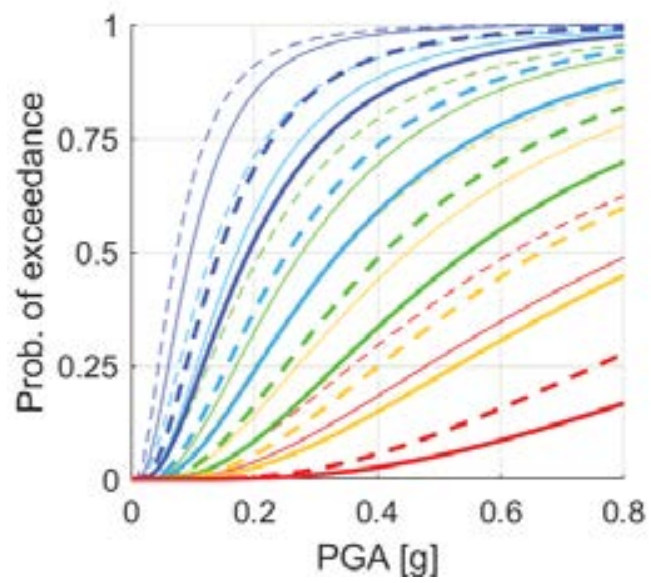

Figure 6: Comparison of fragility sets developed for Pre-1919 buildings in as-built condition and with retrofit for the interventions analyzed.

\section{CONCLUSIONS}

- The paper presents a study that provides mechanical-heuristic seismic fragility curves of Pre-1919 Italian residential masonry buildings, subject to seismic retrofit interventions. In particular, eight type of intervention were analyzed: two steps of intervention concerning the strengthening of the walls (MSN1, MSN2), insertion of tie-rods (TR), stiffening and improvement of diaphragm behavior of the floors (FLR), as well as the combination of these interventions (MSN1+TR, MS1+FLR, MS2+TR, MS2+FLR).

- The software Vulnus 4.0 was used, and the fragility curves (White, Upper-Bound and Lower-Bound) were obtained for eight retrofit solutions, on a dataset of 205 buildings. Then, the procedure by Donà et al. [18] was applied and fragility sets for the retrofit interventions have been derived, so that they could be compared with the as-built fragility curves.

- In general, the results show that masonry strengthening is overall more effective than any other intervention. Moreover, combined interventions are more effective than single ones. It should be noticed that the reduction of vulnerability deriving from a combination of two interventions is not the simple sum of that obtained from individual ones.

- Possible future developments are the extension of this study to residential masonry buildings belonging to construction periods starting from 1919, which have different characteristics and may require different retrofit interventions.

\section{ACKNOWLEDGEMENTS}

Special thanks are due to the Italian Department of Civil Protection (DPC), which funded this study in the framework of the ReLUIS-DPC Project 2019-2021 - Work Package 4: MARS (MAps of Risk and Scenarios of seismic damage) - Task 6: Preventive strategies: comparative analysis in terms of risk on a national scale (Strategie preventive: analisi comparata in termini di rischio a scala nazionale). 


\section{REFERENCES}

[1] Italian Civil Protection Department of the Presidency of the Council of Ministers - DPC, National risk assessment - Overview of the potential major disasters in Italy: seismic, volcanic, tsunami, hydro-geological/hydraulic and extreme weather, droughts and forest fire risks. 2018.

[2] M. Dolce, A. Prota, B. Borzi, F. da Porto, S. Lagomarsino, G. Magenes, C. Moroni, A. Penna, M. Polese, E. Sperenza, Seismic risk assessment of residential buildings in Italy: Methodology overview and main results. Bulletin of Earthquake Engineering, 2020.

[3] F. da Porto, M. Donà, A. Rosti, M. Rota, S. Lagomarsino, S. Cattari, B. Borzi, M. Onida, D. De Gregorio, F.L. Perelli, C. Del Gaudio, P. Ricci, E. Speranza, Comparative analysis of the fragility curves for Italian residential masonry and RC buildings Bulletin of Earthquake Engineering, 2021.

[4] G.M. Calvi, R. Pinho, G. Magenes, J.J. Bommer, L.F. Restrepo-Veléz, H. Crowley, The development of seismic vulnerability assessment methodologies for variable geographical scales over the past 30 years. ISET J Earthq Technol, 43, 75-104, 2006.

[5] M. Rota, A. Penna, C. Strobbia, Processing Italian damage data to derive typological fragility curves. Soil Dyn Earthq Eng, 28(10), 933-947, 2008.

[6] T. Rossetto, I. Ioannou, D.N. Grant, Existing empirical fragility and vulnerability functions: Compendium and guide for selection. GEM Technical Report 2013-X, GEM Foundation, Pavia, Italy, 2013.

[7] A. Rosti, M. Rota, A. Penna, Empirical fragility curves for Italian URM buildings. Bulletin of Earthquake Engineering, 2020.

[8] G. Zuccaro, F.L. Perelli, D. De Gregorio, F. Cacace, Empirical vulnerability curves for Italian masonry buildings: evolution of vulnerability model from the DPM to curves as a function of acceleration. Bulletin of Earthquake Engineering, 2020.

[9] S. Lagomarsino, S. Cattari, Fragility functions of masonry buildings, (Chapter 5), K. Pitilakis, H. Crowley, A.M. Kaynia eds. SYNER-G: Typology Definition and Fragility Functions for Physical Elements at Seismic Risk, Vol. 27, 111- 156, Springer 2014.

[10] D. D’Ayala, A. Meslem, D. Vamvatsikos, K. Porter, T. Rossetto, V. Silva, Guidelines for analytical vulnerability assessment of low/mid-rise buildings. Vulnerability Global Component Project, 2015.

[11] C. Del Gaudio, P. Ricci, GM. Verderame, A class-oriented mechanical approach for seismic damage assessment of RC buildings subjected to the 2009 L'Aquila earthquake. Bulletin of Earthquake Engineering, 16(10), 4581-4605, 2018.

[12] B. Borzi, M. Faravelli, A. Di Meo, Application of the SP-BELA methodology to RC residential buildings in Italy to produce seismic risk maps for the national risk assessment. Bulletin of Earthquake Engineering, 2020.

[13] M. Vettore, M. Donà, P. Carpanese, V. Follador, F. da Porto, M.R. Valluzzi, A Multilevel Procedure at Urban Scale to Assess the Vulnerability and the Exposure of Residential Masonry Buildings: The Case Study of Pordenone, Northeast Italy, Heritage, 3, 14331468, 2020. 
[14] AJ. Kappos, G. Panagopoulos, C. Panagiotopoulos, G. Penelis, A hybrid method for the vulnerability assessment of RC and URM buildings. Bulletin of Earthquake Engineering, 4, 391-413, 2006.

[15] Italian National Institute of Statistics (ISTAT 2001) Website and data warehouse, 2001. https://www.istat.it/it/censimenti-permanenti/censimenti-precedenti/popolazione-e-abitazioni/popolazione-2001

[16] A. Bernardini, M. Gori, C. Modena, Application of coupled analytical models and experimental kowledge to seismic vulnerability analyses of masonry buildings, A. Koridze ed. Earthquake damage evaluation and vulnerability analysis of Building structures, INEEC, Omega Scientific, Ozon, 161-180, 1990.

[17] M.R. Valluzzi, Manuale d'uso del programma Vulnus 4.0, programma originario di A. Bernardini, R. Gori, C. Modena, versione Vb a cura di M.R. Valluzzi, contributi di G. Benincà, E. Barbetta, M. Munari, 2009. (In Italian)

[18] M. Donà, P. Carpanese, V. Follador, L. Sbrogiò, F. da Porto, Mechanics-based fragility curves for Italian residential URM buildings. Bulletin of Earthquake Engineering, 2020.

[19] C. Modena, M.R. Valluzzi, F. da Porto, F. Casarin, Structural Aspects of The Conservation of Historic Masonry Constructions in Seismic Areas: Remedial Measures and Emergency Actions. International Journal of Architectural Heritage, 5, 539-558, 2011.

[20] Y. Saretta, L. Sbrogiò, M.R. Valluzzi, Seismic response of masonry buildings in historic centres struck by the 2016 Central Italy earthquake. Calibration of a vulnerability model for strengthened conditions, Constr. Build. Mater. (in press).

[21] C. Modena, F. Pineschi, M.R. Valluzzi, Valutazione Della Vulnerabilità Sismica Di Alcune Classi Di Strutture Esistenti: Sviluppo E Valutazione Di Metodi Di Rinforzo. Roma: Cnr-Gruppo Nazionale Per La Difesa Dai Terremoti, 2000. (In Italian)

[22] M.R. Valluzzi, F. da Porto, C. Modena, Behavior and modeling of strengthened threeleaf stone masonry walls. Materials and Structures, 37, 184-192, 2004.

[23] N. Mazzon, M.R. Valluzzi, T. Aoki, E. Garbin, G. De Canio, N. Ranieri, C. Modena, Shaking table tests on two multi-leaf stone masonry buildings. $11^{\text {th }}$ Canadian Masonry Symposium, Toronto, Canada, May 31-June 3, 2009.

[24] B. Silva, M. Dalla Benetta, F. da Porto, M.R. Valluzzi, Compression and Sonic Tests to Assess Effectiveness of Grout Injection on Three-Leaf Stone Masonry Walls. International Journal of Architectural Heritage, 8, 408-435, 2014.

[25] C. Modena, F. Casarin, F. da Porto, E. Garbin, N. Mazzon, M. Munari, M. Panizza, M.R. Valluzzi, Structural interventions on historical masonry buildings: review of Eurocode 8 provisions in the light of the Italian experience. E. Cosenza ed. Eurocode 8 Perspectives from the Italian Standpoint, 225 - 236, Napoli, Doppiavoce, 2009.

[26] F. da Porto, M.R. Valluzzi, M. Munari, C. Modena, A. Arêde, AA. Costa, Strengthening of Stone and Brick Masonry Buildings. AA. Costa, A. Arêde, H. Varum (eds) Strengthening and Retrofitting of Existing Structures. Building Pathology and Rehabilitation, vol 9. Springer, Singapore, 2018.

[27] M. Giaretton, D. Dizhur, E. Garbin, J. Ingham, F. da Porto, In-plane strengthening of clay brick and block masonry walls using textile-reinforced mortar. J. Compos. Constr, 22(5), 2018. 
[28] CNR-DT 215/2018, Istruzioni per la progettazione, l'esecuzione ed il controllo di interventi di consolidamento statico mediante l'utilizzo di compositi fibrorinforzati a matrice inorganica. National Research Council, Roma, Italy, 2019. (In Italian)

[29] A. Borri, M. Corradi, G. Castori, A. Molinari, Stainless steel strip - A proposed shear reinforcement for masonry wall panels. Construction and Building Materials, 211, 594$604,2019$.

[30] MLP 1986, Ministry of Public Works, ministerial decree 24/01/1986, norme tecniche relative alle costruzioni antisismiche. (in Italian)

[31] MLP 1981, Ministry Of Public Works, Ministerial Decree No. 198, 02/07/1981, Normativa Per Le Riparazioni E Il Rafforzamento Degli Edifici Danneggiati Dal Sisma Nelle Regioni Basilicata, Campania E Puglia. (In Italian)

[32] M. Vettore, Y. Saretta, L. Sbrogiò, M.R. Valluzzi, A New Methodology for the Survey and Evaluation of Seismic Damage and Vulnerability Entailed by Structural Interventions on Masonry Buildings: Validation on the Town of Castelsantangelo sul Nera (MC), Italy. Int. J. Archit. Herit., 1-26, 2020.

[33] A, Borri, R. Sisti, M. Corradi, A. Giannantoni. Experimental Analysis of Masonry Ring Beams Reinforced with Composite Materials. 16th international brick and block masonry conference, Padua, Italy, 26-30 June, 2016.

[34] G. Magenes, A. Penna, I.E. Senaldi, M. Rota, A. Galasco, Shaking Table Test of a Strengthened Full-Scale Stone Masonry Building with Flexible Diaphragms, International Journal of Architectural Heritage, 8, 349-375, 2014.

[35] M.R. Valluzzi, E. Garbin, M. Dalla Benedetta, C. Modena, In-plane strengthening of timber floors for the seismic improvement of masonry buildings. World Conf. on Timber Engineering (WCTE), Curran Associates, Red Hook, NY, 2010.

[36] M.R. Valluzzi, E. Garbin, M. Dalla Benedetta, C. Modena, Experimental assessment and modelling of in-plane behaviour of timber floors. VI Int. Conf. on Structural Analysis of Historical Constructions (SAHC08), Bath, United Kingdom, July 2nd-4 ${ }^{\text {th }}, 2008$.

[37] E, Giuriani, A. Marini, G. Plizzari, Experimental behavior of stud connected wooden floors undergoing seismic action. International Journal for Restoration of Buildings and Monuments/Internationale Zeitschrift für Bauinstandsetzen und Bau-denkmalpflege, 11(1), 3-24, 2005.

[38] D. Dizhur, M. Giaretton, J. Ingham, URM wall-to-diaphragm and timber joist connection testing. Proc. Int. Mason. Soc. Conf, 2018.

[39] M. Giaretton, I. Giongo, D. Dizhur, Field testing of unreinforced masonry wall-to-diaphragm connection via through-bolt plate anchors and timber blocking. Mason. Int., 32, 63-71, 2019.

[40] M. Ferrini, A. Melozzi, A. Pagliazzi, S. Scarparolo, Rilevamento della vulnerabilità sismica degli edifici in muratura. Manuale per la compilazione della Scheda GNDT/CNR di II livello. Regione Toscana, 2003. (In Italian)

[41] G. Grünthal, European Macroseismic Scale. Chaiers du Centre Européen de Géodynamique et de Séismologie, vol. 15. Luxembourg, 1998. 
[42] M.R. Valluzzi, L. Sbrogiò, Y. Saretta, H. Wenliuhan, Seismic response of masonry buildings in historical centres struck by the 2016 Central Italy earthquake. Impact of building features on damage evaluation. Int. J. Archit. Herit.

[43] Circolare Esplicativa 21 gennaio 2019, n. 7 C.S.LL.PP. Istruzioni per l'applicazione dell' «Aggiornamento delle "Norme tecniche per le costruzioni"» di cui al decreto ministeriale 17 gennaio 2018, Roma, 2019. (In Italian)

[44] M. Donà, P. Carpanese, V. Follador, F. da Porto, Derivation of mechanical fragility curves for macro-typologies of Italian masonry buildings. M. Papadrakakis, M. Fragiadakis eds. 7th ECCOMAS Thematic Conference on Computational Methods in Structural Dynamics and Earthquake Engineering (COMPDYN 2019), Crete, Greece, June 24-26, 2019.

[45] M. Donà, P. Carpanese, V. Follador, F. da Porto, L. Xu, L. Sbrogiò, Seismic fragility and risk of Italian residential masonry heritage. 17th International Brick and Block Masonry Conference (IB2MaC 2020), Kraków, Poland, July 5-8, 2020. 